\title{
LÍA SCHWARTZ, IN MEMORIAM
}

En este año dramático en el que estamos despidiendo a amigos y maestros queridos el fallecimiento de Lía Schwartz se convierte en una inesperada y muy triste manera de acabar 2020.

No es necesario aquí recordar la figura egregia de quien fue generosa y cordial maestra de varias generaciones de hispanistas que vieron -vimosen ella una especie hermana mayor que abría caminos en la investigación y guiaba con afecto y sabiduría a quienes de su mano se acercaron a los estudios auriseculares; acúdase para este propósito a los enlaces accesibles aquí: https://aiso-asociacion.org/triste-noticia-lia-schwartz-in-memoriam/ . Pero sí es el momento de agradecer su apoyo a esta revista a cuyo consejo de redacción se incorporó antes incluso de ser una realidad y, desde el primer número, respondió siempre con prontitud a cuantos requerimientos se le hicieron: cartas de apoyo, posibles revisores, informes de evaluación, asesoramiento sobre temas de volúmenes monográficos, libros para reseñar...

Seguiremos aprendiendo de ella en el recuerdo todavía cercano de sus conferencias; los libros a los que volveremos necesariamente, sus artículos, ediciones - scripta manent-, mas deja un vacío imposible de llenar: sus consejos, sus sugerencias, su conversación brillante salpicada siempre de ironía $\mathrm{y}$ viveza.

Entre tantos adioses, el de Lía es especialmente sentido por la redacción de Hesperia que hoy le rinde tributo de reconocimiento; descanse en paz.

José Montero Reguera

Director 